\title{
Legal Subjects and Juridical Persons: Developing Public Legal Theory through Fuller and Arendt ${ }^{*}$
}

\author{
Kristen Rundle
}

\section{Introduction}

The question of how the agency of persons is shaped by the legal environment that surrounds them is one to which I have returned repeatedly in my work so far. My aim in this article is to develop that question in a new direction. In order to do so, its two main elements need to be teased out. First, there is the focus on persons; specifically, of how law relates to one's status of personhood and the corresponding possibilities for the expression of agency. Second, there is the connection between this possibility and the character of law's form: the structures, relationships, and animating commitments that constitute a given legal environment and distinguish it from some other.

The question of how the agency of persons is shaped by their legal environment is one of legal theory, in terms of our received canon, because it occupied a central place within the jurisprudential program of the mid-twentieth century legal theorist, Lon Fuller. At Fuller's lead, that program had no 'grand theory' ambitions, in the sense of seeking to offer a universal account of the features of law, irrespective of its particular form or context. Rather, the more humble thrust of Fuller's program was to be found in its attention to the relationships, commitments and capacities required for law to be realized and sustained in the world. ${ }^{1}$ This attention to the how of law, and specifically to the role of law's distinctive form(s) in

* This article has benefitted from a number of presentations and readings over the course of its development, each of which generated significant changes to an unruly work in progress. I have many people to thank for their contribution to those improvements, especially Anna Yeatman, David Dyzenhaus, Fred Schauer, James Penner, Nicole Roughan, Andrew Halpin, Patrick Emerton, Dale Smith, Lael Weis, Kevin Walton, Michael Sevel, Martin Krygier, Marcus de Leeuw, Arthur Glass, Wibren van der Burg, and Tamara Pallos. I also wish to convey my sincere thanks to Bart van Klink for the opportunity to participate in this symposium, and to Rudolf Rijgersberg, Michiel Besters, and, above all, Morag Goodwin for their patience and excellent editorial assistance throughout the process. Finally, I am indebted to my four commentators, Michael Wilkinson, Pauline Westerman, Wouter Veraart, and Thomas Mertens, for their formidable efforts in engaging with and challenging me to further develop the ideas contained in this article.

1 This is made especially clear in Fuller's ultimately unfinished 'eunomics' project (his 'science or theory of good order and workable social arrangements'). For an extended discussion of the eunomics project, see Chapter 2 in Kristen Rundle, Forms Liberate: Reclaiming the Jurisprudence of Lon L. Fuller (Oxford: Hart Publishing, 2012) (hereafter: Forms Liberate). 
constituting and sustaining the relationships that Fuller regarded as legal, is arguably his most important and original contribution to legal theory.

These questions are, however, also questions for legal theory prospectively, because the concerns pursued by them have always been, and ultimately remain, under-developed. This has much to do, I think, with the difficulties in finding a theoretical space within which to situate a program of this kind. Where that program found primary expression in Fuller's work - his interventions in what became the famous 'Hart-Fuller debate' - was not necessarily the most congenial place for its clarification and development. ${ }^{2}$ Though Fuller's offerings there can be seen as an effort to translate questions and insights about legal forms and their constitutive relationships across into received philosophical contests about the connections between law and morality, his project is not and never was a clear instance of a classic 'natural law versus legal positivism' debate. While there might have been a manner to fit his thoughts within that debate, Fuller's questions were more often than not wider than this narrow frame allowed, making them, and indeed him, an awkward fit within the field as it was then developing and has largely continued to develop since. ${ }^{3}$

There remain, therefore, real questions to be asked about how we might understand Fuller's interests as a program for legal theoretical inquiry in its own right, and how that program might today provide the starting point for novel trajectories of inquiry. This question animated the concluding remarks of my study of Fuller's jurisprudence in Forms Liberate, and this paper represents an effort to take up from where I there left off. ${ }^{4}$ Specifically, my aim here is to direct the question of how Fuller's program might provide foundations for new inquiry towards the development of normative legal theory with a distinctly public, or political, aspect.

I do not have in mind here 'public law theory' in the sense of the scholarly enterprise that seeks to theorize the conditions for constitutionalism, or which is

2 The full exchange of the 'Hart-Fuller debate' consists of H.L.A. Hart, 'Positivism and the Separation of Law and Morals,' Harvard Law Review 71 (1958): 593, and Lon L. Fuller, 'Positivism and Fidelity to Law - A Reply to Professor Hart,' Harvard Law Review 71 (1958): 630. Hart and Fuller's exchange then continues through H.L.A. Hart, The Concept of Law (Oxford: Oxford University Press, 1961); Lon L. Fuller, The Morality of Law (New Haven: Yale University Press, 1964); H.L.A. Hart, 'Lon L. Fuller: The Morality of Law,' Harvard Law Review 78 (1965): 1281, reprinted in H.L.A. Hart, Essays in Jurisprudence and Philosophy (Oxford: Clarendon Press, 1983), and Lon L. Fuller, 'A Reply to Critics,' in the second edition of The Morality of Law (New Haven: Yale University Press, 1969).

3 My point here is that this frame was not just any instance of the traditional 'natural law versus legal positivism' debate, but one convened by Hart on terms specifically designed to serve his reelaboration of the merits of positivist legal philosophy. Fuller's desire, in reply, to illuminate what positivist legal philosophy did not do well did not necessarily map neatly onto that very specific discussion of the connections between law and morality, and which went primarily to the question of the moral quality of law's ends. It is precisely because Fuller's challenges burst the boundaries of that narrow frame that many of his contemporary interpreters have attempted different ways of liberating his project from that agenda: See, e.g., Rundle, Forms Liberate, 4-7.

4 Rundle, Forms Liberate, 203. 
otherwise concerned with understanding law's constitutive role in the activity of government. ${ }^{5}$ Rather, in speaking of normative legal theory in its public or political aspect, or indeed 'normative public legal theory,' I have in mind a trajectory of inquiry that works broadly within the tradition of rule of law theorizing, and which specifically aligns the normative objective of the rule of law with the protection of persons from the exercise of arbitrary political power, however the term 'arbitrary' might be understood. Fuller, of course, has long been widely regarded as occupying a leading place in this tradition, with the eight principles of his 'internal morality of law' considered by many as the starting point for providing an account of the rule of law, both descriptively and normatively. In contemporary legal theory, however, precisely where we ought to place Fuller's contribution, and why, is not necessarily as clear as it might historically have been, as several conflicting endeavours now occupy 'rule of law' inquiries. That is, not only does this broad term point to the work of those who continue the debates of the major camps of legal philosophy through exploring the content and philosophical implications of the idea of the rule of law, ${ }^{6}$ but also between those who seek to associate the normative objective of that idea primarily with the security of private property. The increasingly diffuse scope and aims that can be attributed to the task of conceptualizing the conditions of the rule of law thus suggests that precisely how Fuller's jurisprudence contributes to that tradition in its former, explicitly 'public,' aspect is a matter worth not just revisiting, but developing further.

In this article, I consider that question through an emphasis on how the 'public' character of the kind of rule of law theorizing with which Fuller was engaged is signalled especially in his attention to the very notion of being a 'legal subject' at all. This term is not one we associate with the vocabulary of private law, where we instead expect such language as that one is the 'party to' a contract, the 'beneficiary' of a trust, the 'bearer' of some private law right, or some equivalent construct. To speak of being a 'legal subject,' by contrast, is to speak in a vocabulary that has meaning only when the circumstances at issue concern the place of persons within a public realm of law. An idea of 'publicness' is thus implicit in the very idea of legal subjectivity.

This point is central to the work I aim to do in this article in exploring the animating commitments of a particular species of normative public legal theory that commences its inquiry from an assessment of the conditions of personhood within a public legal frame. Though I regard Fuller as something of a torchbearer for such a direction of legal theorizing, it is nonetheless one that we are yet to fully explore at the level of either substance or method. On the matter of substance, we can take from Fuller the idea that the position of a legal subject within a putative legal order is central to an assessment of the presence of the legal condition itself, its claims to authority, and the dependence of both on the

5 Exemplified in Martin Loughlin, The Idea of Public Law (Oxford: Oxford University Press, 2003).

6 Exemplified in Joseph Raz's response to Fuller in 'The Rule of Law and its Virtue,' Chapter 11 in The Authority of Law - Essays on Law and Morality (Oxford: Clarendon Press, 1979). 
observance of the distinctive ethos (or 'office') of the public lawgiving role. ${ }^{7}$ It is by looking at these conditions occupied by the subject that Fuller's approach illuminates the characteristics of the constitutive relationships that he regards as distinguishing 'legal' modes of ordering from 'non-legal' ones. ${ }^{8}$ I have argued this point elsewhere, and I retrace it in section 2 below. But what I have addressed much less in my analysis and development of Fuller's jurisprudence so far are the questions of methodology that attach to the choice to commence one's theoretical inquiry by seeing things from the subject's perspective, as if such a perspective provides a kind of 'lithmus test,' an ultimate normative standard, for assessing the presence or absence of a public condition of law.

The overriding aim of this article, therefore, is to ask what is demanded of a project of distinctly public normative legal theory that commences from the question of how the personhood, status and agency of persons is shaped by the legal environment that surrounds them. What are the defining commitments of such an approach, on matters of substance and method alike? I pose this question in general terms, rather than as directed to the development of Fuller's work specifically, because even if he might be regarded as its mid-twentieth century torchbearer, the endeavour of developing modes of normative legal theorizing specifically concerned with public rather than private legal relationships is one that I regard as a program of inquiry in its own right. As such, it invites consideration of resources beyond Fuller. It is in its pursuit of this last thought that this article makes its most novel move: namely, its effort to engage those elements of Fuller's project that speak to the conditions of legal personhood with the idea of 'juridical personhood' found in the work of the mid-twentieth century political theorist, Hannah Arendt.

Given that Fuller and Arendt are rarely (if ever) sighted as companions in the same inquiry, the proposed move requires some explanation and defence. Nothing that follows seeks to propose that we should view Fuller and Arendt as equivalent in terms of the ultimate intellectual contribution that each made; few would disagree that Arendt's stature stands above Fuller's. More specifically, however, it is important to clarify at the outset that the engagement with Arendt that I undertake here is a highly circumscribed one, directed to an interaction with specific sites of her thought only, and without seeking to attribute aims or claims in the usual sense. Nowhere in what follows, therefore, will be found anything to the effect that Arendt argued some or other point about the nature of the legal condition, or otherwise intentionally offered material for normative legal theorizing. Indeed, having been directly affected by the institutional collapse wrought by Nazism, Arendt was deeply sceptical about the value of institutions to persons, legal or otherwise: for her, the focus had to be on pre-institutional questions of politics. It thus seems right of her interpreters to insist that when Arendt's con-

7 Whether Fuller himself envisaged that these reflections could or should be directed towards questions of law's public or political aspect is a question to which I will return in section 4 .

8 A point most strongly argued by Fuller through his analysis of the distinction between law and managerial direction, to which I return below. 
sideration of questions of politics led her to reflect upon the phenomenon of law, such as when she revisited the ancient conceptions of nomos and lex, ${ }^{9}$ we can at most take those reflections as suggestive only. ${ }^{10}$

The proposition I wish to defend, however, is that there are nonetheless several striking commonalities between Fuller and Arendt on points of both substance and method. For example, even if apparently differently motivated, their common interest in conditions for agency and action saw each lament the dominance of negative conceptions of freedom ('freedom from') over positive conceptions ('freedom to'). For Arendt, the priority given by the modern tradition to the idea of negative freedom ignores lessons we might take from political revolution that suggest that freedom is in fact achieved in concert with others, not in isolation from them. ${ }^{11}$ Fuller explored different, though I would suggest broadly, compatible points, in his interest in the conception of the person (someone capable of purposive action) underlying the notion of 'freedom to' as opposed to 'freedom from, ${ }^{12}$ as well as in his critique of the distinction itself as analytically untenable, given that actual social arrangements invariably involve the interaction of both. ${ }^{13}$ In a closely related vein, Fuller and Arendt both also articulated strident critiques of the command conception of law and its theoretical impact on their respective

9 Arendt's consideration of the Greek conception of law as nomos (law as the boundary that constitutes the space within which political action can take place) and the Roman conception of law as lex (in which law subsists in the relation between entities, in the vein of promise and contract) has been a major focus of those who have recently sought to illuminate the explicit or implicit engagements with questions of legal theory in her writings. See especially Michael Wilkinson, 'Between Freedom and Law: Hannah Arendt on the Promise of Revolution and the Burden of "The Tradition," and Keith Breen, 'Law beyond Command? An Evaluation of Arendt's Understanding of Law,' in Hannah Arendt and the Law, ed. Marco Goldoni and Christopher McCorkindale (Oxford: Hart Publishing, 2012), as well as Peg Birmingham, 'Hannah Arendt's Philosophy of Law Approach to International Criminal Law,' International Criminal Law Review 14 (2014): 695-716.

10 This is because Arendt herself ultimately did not settle a view as to her preference between the ancient conceptions of nomos and lex. Still, there seems to be broad agreement that lex, with its emphasis on promising and its orientation towards collaboration and agreement, comes out ahead, and this seems supported by Arendt's interest in Montesquieu's 'spirit of the laws' idea, which she sees as capable of supporting a view of law that prioritises relationships of consent. See, on this point, Wilkinson, 'Between Freedom and Law,' and Birmingham, 'Hannah Arendt and Judith Shklar: The Public Authority of International Law.'

11 See the essay 'What is Freedom,' in On Revolution (London: Penguin, 1963): 195.

12 See Lon F. Fuller, 'Freedom: A Suggested Analysis,' Harvard Law Review 68(8) (1955): 1305-25, at 1307, 1314.

13 See Fuller's 1958 lecture 'The Case Against Freedom,' where he employed the vocabulary of 'negative' and 'affirmative' freedom to make this point: see the reproduction of this lecture in Kenneth I. Winston, The Principles of Social Order - Selected Essays of Fuller, Lon L. (revised edition) (Portland: Hart Publishing, 2001), 315. These themes were then reiterated and further developed in his 1968 essay, 'Freedom as a Problem of Allocating Choice,' which again criticizes the contemporary philosophical focus on conceptions of negative liberty, and again for reasons of the distance of this conception from what must inform the task of convening social arrangements: see Proceedings of the American Philosophical Society 112(2) (1968): 101-6. 
fields of inquiry. ${ }^{14}$ Here, Arendt's complaints are underscored by much more explicitly political concerns than Fuller's. For her, the command conception has its own political program in so far as it reflects a conceptual choice to retreat to an idea of rule that enables us to escape the unavoidable relationships of politics through recourse to a top-down, absolute conception of authority. Fuller's critique of the command conception, by contrast, was foundational to his objections to positivist legal philosophy generally, and so on its face would appear preoccupied with strictly legal concerns. ${ }^{15}$ Nonetheless, what underscores both critiques is a foundational interest in the vision of legal life that is imagined by conceptions of law that align with a source of absolute authority, and how, in turn, such conceptions envisage and speak to the legal subject.

There is arguably still more in common between Fuller and Arendt when we turn to matters of method. In both, we see an unswerving commitment to keeping practice in view so that our efforts at theorizing might learn from the history of human experience. Both also share a deeply diagnostic orientation, especially when directed towards identifying the centres of gravity and biases of the dominant theoretical accounts against which they each attempted to mark out the territory for novel (or reclaimed) inquiry. ${ }^{16}$ Indeed, one gets the sense when reading both Fuller and Arendt that they engaged in something perhaps not best described as theory-making, at least if such is understood as aimed at systematic, free-standing accounts. Rather, theirs is a different kind of endeavour: an effort to trace out the implications, for theory, practice, or politics, as the case may be,

14 Arendt's reason for criticizing the 'imperative' or 'command' conception of law was intimately associated with her critique of the equal tendency of modern political theory to embrace a 'negative' conception of freedom, and so to associate the conditions of human flourishing with the absence of the will of others. As she saw it, this view ignores the lessons we might take from political revolution, where we see that freedom is in fact achieved in concert with others, not in isolation from them. It was precisely a desire to consider alternative conceptions of law that could be possibly generative of the kind of politics to which she was committed, rather than unaligned with and potentially destructive to such politics, that motivated Arendt's revisitation of the ideas of nomos and lex mentioned above: see specifically Hannah Arendt, The Human Condition (Chicago: University of Chicago Press, 1958), 222, and Arendt, On Revolution, 195, as well as Wilkinson, 'Between Freedom and Law' and Breen, 'Law beyond Command?'

15 In Fuller's eyes, positivist legal philosophy was by definition committed to a view of law along the lines of that conception because of the top-down, official-centric, minimally-interactional, subject-neglecting shape of legal relationships that it presented. Even H.L.A. Hart's novel interpretation of that tradition, which itself criticized the command conception on descriptive grounds, did not dismantle this way of presenting the relationships constitutive to an order of legality, because for Fuller, Hart's 'rule of recognition' seemed 'designed to exclude the notion that there could be any rightful expectation on the part of the citizen that could be violated by the lawgiver': Fuller, The Morality of Law, 140, and also, much earlier, 'American Legal Philosophy at Mid-Century - A Review of Edwin W. Patterson's Jurisprudence, Men and Ideas of the Law,' Journal of Legal Education 6(4) (1954): 457-85.

16 I refer here to how both Fuller and Arendt lamented the loss of various wisdoms from 'the ancients,' as demonstrated, for example, in Fuller's frequent references to Aristotle (see, e.g., The Morality of Law, 5, 19, 64, 94), and Arendt's revisitation of nomos and lex in On Revolution. 
of the phenomenon under study. ${ }^{17}$ This might go some way towards explaining why those of us who are attracted to either or both of them tend to be so much less for their contributions to extant traditions, than for their attempts at gamechanging originality and the reclamation of lost wisdom. In short, however their efforts were ultimately received, Fuller and Arendt did things differently and so, unsurprisingly, also often lamented the apparent solitude of their programs amid prevailing intellectual fashions.

These general commonalities between Fuller and Arendt provide a background for the very specific resonance that I explore in the pages to follow on the matter of being a 'legal subject' or, in Arendt's language, a 'juridical person.' Arendt's reflections on the 'juridical person' emerge through her consideration in The Origins of Totalitarianism of the three kinds of killing of the person - the killing of the juridical person, the killing of the moral person, and the killing of the individual - that supply the conditions for total domination. ${ }^{18}$ The argument I elaborate in section 3 below is that we might read this analysis as suggesting important things about a condition of the 'juridical': namely, how it is one in which the structure and commitments of the public legal form constitute a distinctive species of personhood vis-à-vis political power that is unavailable if one is positioned outside of that frame. Equally of interest in that analysis is how Arendt gestures to the idea that this condition of the juridical is to be distinguished from an idea of legality understood purely in terms of the presence of positive law, however sourced and sustained.

These reflections indicate a perhaps unexpected direction of normative legal theoretical thought within Arendt's argumentation on ostensibly separate questions, and are intriguing for this reason alone. But for present purposes, Arendt's commentary on the juridical person is of special interest for how it shares much with the central elements of Fuller's thinking on the character of and conditions for being a legal subject. In drawing this comparison, however, my objective is not just to highlight similarities for similarity's sake. Rather, as I will argue in section 4, the comparison itself provides a fruitful foundation from which to explore wider questions about the required content and methods of a distinctly public normative legal theory that commences its analysis from an appraisal of the position of persons within a putative legal frame.

There are a number of reasons why I regard it as especially helpful to engage with Arendt in the development of this thought. To begin with, her questions are consistently public or political, and so when Arendt reflects upon things legal, she does so with this perspective in view. It follows that we can arguably take more from the explicitly 'public' quality of her reflections on legal personhood than we

17 Fuller in fact suggested in a letter to Hart that legal philosophers might fruitfully engage in 'tracing out the implications' of our institutions: see letter from Fuller to Professor H.L.A. Hart, October 19, 1959, The Papers of Lon L Fuller, Harvard Law School Library, Box 14, Folder 1 ('The Forms and Limits of Adjudication': correspondence), quoted in Rundle, Forms Liberate, 43. 
can from Fuller on the same point, because for Arendt, juridical personhood is its own kind of political status. Engaging with Arendt's analysis similarly invites us to reflect more deeply on the kind of methodology that supports this kind of theoretical orientation, given her ease with - indeed her advocacy of - opening our theoretical reflections to sociological and empirical contingencies that are so often avoided by legal theorists.

I continue, therefore, by first setting out how Fuller's understanding of the character of public legal personhood connects to the central claims and methods of his jurisprudence. I then turn to Arendt's reflections on the 'juridical person,' drawing out the direction of the intuitions from The Origins of Totalitarianism that I recognize as resonating with the kind of questions with which I am here concerned. I then move to consider what the suggestions received from both scholars' analyses signal for how we might develop a distinctive project of normative legal theory, concerned with law's public aspect, which pivots on the status of persons within the legal frame.

\section{Legal theory through the legal subject: the contribution from Fuller}

From the very beginning of his writings in jurisprudence, Fuller was interested in the different ways that the human interactions constitutive to different modalities of legal ordering generate, accommodate, or promote the expression of human agency. To frame it in language now common in legal philosophy, these interests of Fuller's concern the non-instrumental dimensions of law: that is, those aspects beyond, or separable to, law's role as a vehicle for the pursuit of some or other end. ${ }^{19}$ In his jurisprudence, therefore, we are asked to see that alongside its instrumental capacities and value as a means to ends, law has an association with the channelling and expression of agency that is constitutive to its distinctiveness as a modality as well as to its value to human endeavour.

The complaints Fuller advanced about the project of legal positivism in one or other way express this preoccupation with the non-instrumental dimensions of law, challenging positivists to situate or address these dimensions within their account of law. For Fuller, not just the ideal of the rule of law but law itself runs out when these non-instrumental presuppositions of legality are not adequately respected and realized. For positivists, of course, these are two separate issues: achieving law itself is one thing, and achieving law that complies with the ideal of the rule of law another. ${ }^{20}$ Navigating this debate between Fuller's jurisprudence

19 For a recent development and defence of non-instrumental legal theoretical inquiry, see Alon Harel, Why Law Matters (Oxford: Oxford University Press, 2014).

20 The most famous elaboration of this positivist response to Fuller is Joseph Raz's essay, 'The Rule of Law and its Virtue.' For a more recent and essentially identical response, see John Gardner, 'On the Supposed Formality of the Rule of Law,' in Law as a Leap of Faith (Oxford: Oxford University Press, 2012). I have recently responded to the latter formulation in Kristen Rundle, 'Gardner on Fuller: A Response to "On the Supposed Formality of the Rule of Law," Jurisprudence (2015, forthcoming). 
and legal positivism - and, specifically, reading it from Fuller's perspective - was central to my aims in Forms Liberate. In particular, I sought to explain how his controversial arguments about law's 'internal morality' ${ }^{21}$ should be understood as directed to the demands of ethos on the part of the lawgiver that are reflected in the eight principles of lawgiving, as well as the value of respect for agency that this ethos expresses towards the legal subject.

Here, however, my concerns lie more squarely with what might be generated, for a distinctly public legal theory, out of the cluster of ideas concerning the character of legal personhood and its relationship to law's distinctive public institutional frame that travel together in Fuller's writings on the internal morality of law. A consistent feature of those writings is Fuller's criticism of the apparent lack of attention by legal positivists to the conditions of subjectivity (if any) that we attach to our theorizing about law. ${ }^{22}$ It is through these objections, therefore, that we find important indications about what Fuller thought it meant to actually be a legal subject. This, he suggested in a working note, is clearly not merely to be a member of 'a subservient populace ready to do what they are told to do.' It is, instead, to be a participant in a distinctly constituted social condition in which one is respected as an agent. ${ }^{23}$

In Fuller's published writings, the question of what it means to be a legal subject is addressed in different ways. In his reply to Hart on the status of Nazi law, for instance, Fuller's attention to the position of the subject is central to the challenge he puts to Hart to explain not just why but how, by virtue of its frequent unintelligibility and arbitrariness, the 'conscientious citizen' could possibly be expected to obey Nazi law. ${ }^{24}$ The question of law's authority - more specifically, accounting for the question of law's authority as part of an account of law itself - is thus explored by looking to the position and capabilities of the legal subject, and assessing the question from that perspective. In The Morality of Law, however, the question that turns Fuller towards the legal subject is different.

21 That is, the eight principles Fuller extrapolates from his tale of the hapless lawgiver, Rex, who failed in eight different ways to make law: that law be general, publicly promulgated, clear, noncontradictory, possible to comply with, relatively constant through time, non-retroactive, and that there be congruence between official action and declared rule: see generally The Morality of Law, Chapter 2.

22 The working notes for Fuller's final reply to his critics, for instance, speak repeatedly of positivism's neglect of 'the other fellow,' the legal subject: see my analysis of these papers in Chapter 5 of Forms Liberate. Positivist legal philosophers subsequent to Hart have, however, diluted Fuller's concern, in so far that they pay attention to the perspective of the subject of legal authority. Joseph Raz's work on authority, as part of his development of positivist legal philosophy, is a leading example. It is therefore not my intention here to suggest that positivists, consistently, ignore the questions relating to the position and perspective of the legal subject. Rather, my intentions can be distinguished from these positivist efforts in at least two respects: first, in the explicitly 'public' orientation of legal theory I am concerned to explore, and second, in the association of what is here investigated with an explicitly normative theoretical program.

23 Undated and untitled document, The Papers of Lon L. Fuller, Harvard Law School Library, Box 12, Folder 1 (Notes for the 'Reply to Critics'). 
Here his task is to explain and defend his controversial use of the term 'morality' to describe the requirements of the ethos of lawgiving that he enumerates through his eight principles of the 'internal morality of law.' One answer to this question, he explains, lies in the conception of the person implicit in the very possibility of a condition of legality so understood, and which is a 'moral' dimension of law quite separable from the question of the morality or justice of specific legal ends. As he explains the point:

'I have repeatedly observed that legal morality can be said to be neutral over a wide range of ethical issues. It cannot be neutral in its view of man himself. To embark on the enterprise of subjecting human conduct to the governance of rules involves of necessity a commitment to the view that man is, or can become, a responsible agent, capable of understanding and following rules, and answerable for his defaults.

Every departure from the principles of law's inner morality is an affront to man's dignity as a responsible agent. To judge his actions by unpublished or retrospective laws, or to order him to do an act that is impossible, is to convey to him your indifference to his powers of self-determination. Conversely, when the view is accepted that man is incapable of responsible action, legal morality loses its reason for being. To judge his actions by unpublished or retrospective laws is no longer an affront, for there is nothing left to affront - indeed, even the verb "to judge" becomes itself incongruous in this context; we no longer judge a man, we act upon him.'25

I have engaged with this passage on several occasions in my work on Fuller so far, ${ }^{26}$ and in this practice am joined by a number of other scholars who equally see its message as crucial to the proper interpretation and development of his jurisprudence. ${ }^{27}$ Presently, however, I am much less concerned with what the argument contributes to a defence of the 'morality' frame of his response, than with the two ways in which the argument appears to run.

The first is in the direction of the capacities presupposed in a legal subject. Here we receive a message about what we might call capability for law. One must, Fuller tells us, be capable of 'responsible agency' to be able to follow rules and to be answerable for one's defaults. To be a legal subject, then, requires that the person be 'ready for' and capable of the demands of participation that come with an engagement with the legal enterprise.

Fuller, The Morality of Law, 162-3. I have elsewhere commented on the obvious level of hyperbole in this passage, in terms of its suggestion that 'every departure' from the principles of the internal morality of law is an 'affront' to the responsible agent: see, for example, Forms Liberate, 98-99.

26 See Chapter 4 of Forms Liberate, and Kristen Rundle, 'Law and Daily Life: Questions for Legal Philosophy from 1938,' Jurisprudence 3 (2012): 429-44.

27 See, for a recent example, Jeremy Waldron, 'How Law Protects Dignity,' Cambridge Law Journal 71 (2012): 200. 
The second direction of the argument speaks to the capacities, or status, constituted or created, or indeed taken away, by virtue of how the person is engaged with by the (putative) surrounding legal frame. This line of the argument, with which I am most interested here, appears to concern the condition, or status, of personhood that arises because of law. The point is boldly put: the conditions for being a legal subject are generated out of a certain quality of interaction with authority that is itself generated by the animating commitments of the distinctive form of law. Or, put in reverse, the suggestion is that these conditions and qualities will not be generated in the absence of those interactions and commitments, because in such an instance, one is not a legal subject, but rather merely acted upon. Thus, the argument runs, law speaks to agency, and so must also respect and sustain the capacities of the legal subject as a centre of initiative. It must do this, moreover, not just as an abstract philosophical commitment, but as one rendered tangible through the legal institutional complex through which a subject experiences her relationship with authority.

Consistent with the normative orientation of his jurisprudence generally, it follows that for Fuller the very status of being a legal subject is necessarily a contingent one. Certain institutional conditions must be in place, and observed, for the status itself to be generated and sustained. But we must also notice how, in the passage, the shift from 'law' (where the subject's capacity for responsible agency is acknowledged and respected) to 'acting upon' (where it is not) appears to manifest for one of two reasons. The first is because 'the view is accepted' that the subject is 'incapable' of responsible action. This incapacity, we might surmise, could be attributable to a range of factors, including age or disability, which go to a person's capability to take on the responsibilities of legal relationships. But we are also told that the shift from 'law' to 'non-law' might occur if the putative lawgiver interacts with the subject through the medium of formally debased law. This is a different way of rendering a person into something unintelligible to law, such that they are merely acted upon. As Fuller himself explains, to judge the subject by reference to such debased forms as retroactive or unpublished laws is not to have merely affronted the subject's status as a responsible agent, but to have done something much worse: to have basically negated it altogether.

The message, therefore, is that there is an inherent incompatibility between the particular institutional demands of a condition of legality and certain ways of envisaging, and treating, the legal subject. Moreover, it is clear that, on this view, a person's standing and capacities vis-à-vis the site of political authority is never a given: it is always attached to the status that one is afforded within the surround- 
ing institutional frame. ${ }^{28}$ Legal personhood is a condition that must be institutionally generated, and not a condition to be merely assumed by the apparent presence of law in a positive sense. This is also, I have argued, the message underscoring Fuller's exposition of his idea of the internal morality of law. To see this, however, it is essential that we not read his famous list of eight principles as a kind of 'checklist' that law must satisfy, in all cases, in order to be law. ${ }^{29}$ Rather, the model of the internal morality of law speaks above all to the distinctive kind of relationship between authority and those subject to it that is brought into being, regulated, and served by its principles, and which has material implications for the status of personhood experienced within an institutional frame that is compliant with those principles. ${ }^{30}$ This is, of course, precisely the point Fuller made in the 'last word' of the Hart-Fuller debate - his 'Reply to Critics' - when he argued that legal positivism actually articulates and defends a conception of managerial direction rather than law. As he elaborated the point, the only way that one can take a purely instrumental, 'efficacy'-led reading of the value served by observance of the internal morality of law is if it attaches to a top-down conception of law in which the role of the subject is merely to serve the superior's ends. And

28 An analysis compatible with this point has recently been presented by Jeremy Waldron, also in conjunction with an analysis of Fuller, but specifically addressing the argument that law itself inherently protects dignity (and not just in its contingent association with human rights). Waldron explains that dignity is a 'status concept,' and thus 'has to do with the standing (perhaps the formal legal standing or perhaps, more informally, the moral presence) that a person has in a society in her dealing with others': Waldron, 'How Law Protects Dignity,' 201. Indeed, Waldron's account of what it is that the status of dignity affords to the person, and to which Waldron argues law speaks directly (202), resonates strongly with the arguments of the present analysis.

29 Rundle, Forms Liberate, 10, 92. This reading of Fuller has not only promoted a 'one size fits all' understanding of the eight principles, but also a highly instrumental and indeed positivist-compatible conception of the rule of law as that which complies with 'Fuller's eight' and achieves lawgiving efficacy by doing so. See Hart's famous argument, elaborated further below, in response to Fuller in his 1965 review of The Morality of Law: Hart, 'Lon L. Fuller: The Morality of Law').

30 Rundle, Forms Liberate, 10, 3, 101, 116-17. This point about how the legal frame must by the nature of its relational structure envisage and relate to its subjects is also made clearly, in different ways, in other sites within Fuller's canon. One is the story of a tyrant who, bent entirely on employing his subjects 'as tools for the realization of his purposes,' sets out to become a lawgiver. The tyrant soon arrives at a number of important insights about the incompatibility between his aims and his chosen method: how, though he might have started with a desire to instrumentalize his subjects in service of his ends, he ended up 'fostering the conditions most conducive to human development': see 'Freedom as a Problem of Allocating Choice,' 105. See my treatment of the tyrant story in Rundle, Forms Liberate, 108-111. Another point to emphasize about the tyrant story is how this bit of hypothetical play, which I have argued marks an important progression from the tale of Rex, belongs to the same time period in which Fuller penned his final 'Reply to Critics' and its analysis of the distinction between law and managerial direction (see next note and accompanying text). The shared emphasis within these two ostensibly unrelated works on how law must by the nature of its relational structure envisage its subjects is thus to my eyes no accident, and, moreover, consistent with the comments just emphasized about the conception of the person implicit in legality. 
this, to Fuller's eyes, is ultimately a conception of managerial direction rather than law. ${ }^{31}$

Fuller's thinking on the conditions for law's authority - its claim to our 'fidelity' - reproduces this fundamental emphasis on how law's formal frame sustains a certain quality of relationship between a public authority and its subjects. This is clear not only from the frame of Fuller's initial reply to Hart in the 1958 Harvard Law Review, which puts the 'fidelity to law' point front and centre, but especially from the thrust of Fuller's reply to Hart on the matter of Nazi law. Why, he there asked, would anyone accept law's authority and demonstrate their commitment to it if - as Hart's analysis of Nazi law certainly suggested - it is merely a tool through which authority can do with you as it will? ${ }^{32}$ This challenge then becomes a key feature of Fuller's position when, in The Morality of Law, he explains how a subject's fidelity to law can and likely will break down when the requisite mutuality of obligation between lawgiver and subject lapses. As he expresses it, 'there can be no rational ground for asserting that a man can have a moral obligation to obey a legal rule that does not exist, or is kept secret from him, or that came into existence only after he had acted, or was unintelligible, or was contradicted by another rule of the same system, or commanded the impossible, or changed every minute. 33

The point to note is that this release from moral obligation does not arise because it is necessarily practically impossible to obey such a rule (though it might well be). It instead arises from how the legal subject's moral obligation to obey law is generated in the first place, in response to or in anticipation of the lawgiver's corresponding effort. ${ }^{34}$ This point is interesting for present purposes because the subject's withdrawal of her fidelity to law in such a situation might itself be understood as an assertion of her legal personhood. That is, Fuller is clear that the status of legal personhood has conditions, just, indeed, as does the status of being a lawgiver. If the reciprocal obligations that sustain these conditions break down, the subject is entitled to opt out of the relationship: this is her way of asserting, or policing, the conditions of her legal personhood. And once this occurs, the legal condition itself will also break down.

31 Fuller, 'Reply to Critics,' 207-8. This argument is made in response to Hart's argument that the so-called 'moral' principles of the 'internal morality of law' are merely neutral aids to the effectiveness of the lawgiving task, no different to principles that one would follow to make the activity of poisoning effective (see my analysis of Hart's review in Chapter 4, Forms Liberate). It is in his elaboration of the law/managerial direction distinction that we see Fuller single out those of his eight principles that go to the equality, stability and intelligibility of the subject's position in the face of authority expressed through law, and which he insists are irrelevant to a frame of managerial direction: namely, the principles of generality, non-retroactivity, and congruence between official action and declared rule: 'Reply to Critics,' 209-10.

32 Jeremy Waldron's 1994 essay, 'Why Law? Efficacy, Freedom, Fidelity' marked the turn towards understanding Fuller correctly on this point: see Law and Philosophy 13 (1994): 259-84.

33 Fuller, The Morality of Law, 39.

34 Otherwise, 'nothing is left on which to ground the citizen's duty' to observe the lawgiver's rules: Fuller, The Morality of Law, 40. See discussion in Rundle, Forms Liberate, 3, 89-92. 
It is clear, then, that the (inherently contingent) status of being a legal subject, the formalized structure of commitments towards the subject through which lawgivers or legal officials act, the conditions for the very existence of an order of legality, and at least part of the explanation for why law carries its distinctive kind of authority, are ideas that travel closely together in Fuller's jurisprudence. ${ }^{35}$ For present purposes, what we have learned from revisiting those ideas is how, for Fuller, the statuses and offices of the 'legal,' lawgiver and subject alike, come into being because, and only because, of the institutionally generated and supported interactions that are constitutive to those statuses. Certainly, the subject must initially possess what I earlier described as capability for law, prior to entry into the legal condition. But the point being highlighted here concerns what comes into being, in terms of a distinctive status or species of personhood, by virtue of one's inclusion within a legal frame. It is this point that resonates with Arendt's reflections on juridical personhood, which equally traverse questions concerning how this distinctive and politically crucial status is created, sustained, and lost.

\section{Legal theory through the 'juridical person': the contribution from Arendt}

Arendt's figure of the 'juridical person' does not appear in association with her critique of the command conception of law, nor with her related interest in the alternate legal conceptions of nomos and lex, but rather in her exploration of totalitarianism and the Nazi system in The Origins of Totalitarianism. It is in her discussion of the conditions for total domination that we meet the juridical person directly, though (on my reading at least) essentially the same idea is present in Arendt's discussion of the 'Perplexities of the Rights of Man' earlier in the same text. I therefore start with that passage with a view to showing that what emerges from Arendt's reflections on things 'juridical' and the implications of this condition for personhood is not only normatively substantial in its own right, but also registers the same nexus between conditions of personhood and law's institutional frame that I have just outlined in Fuller's jurisprudence.

Arendt's discussion in the 'Perplexities of the Rights of Man' is among one of the most well-known commentaries on the significance of citizenship - 'the right to have rights' - in contemporary political theory. In it, Arendt highlights the implications of 'the identification of the rights of man with rights of peoples in the European nation state system' by reference to the lessons learned from the position of stateless persons within that system; what she described as 'the calamity of an ever-growing body of people forced to live outside the scope of all tangible law. ${ }^{36}$ There is no doubt that this analysis of why citizenship matters is Arendt's primary interest in the relevant passage. What I want to suggest here, however, is that the way that Arendt teases out her arguments signals a deeper and more gen-

35 I am less concerned here to expand upon the question of how the actions and attitudes of the legal subject inform the conditions for law's authority in Fuller's thought, though I do return briefly to the question of authority in section 4 below.

Arendt, The Origins of Totalitarianism, 291, 293. 
eral point about the implications of what might be called institutional statuslessness'. The relevant insights emerge in a passage that, for all its apparent irony, conveys a stark message. As Arendt argues, 'as the anomaly for whom the general law did not provide,' it was better for the stateless person 'to become the anomaly for which it did provide, that of the criminal': ${ }^{37}$

'The best criterion by which to decide whether someone has been forced outside the pale of law is to ask if he would benefit by committing a crime. If a small burglary is likely to improve his legal position, at least temporarily, one may be sure that he has been deprived of human rights. For then a criminal offense becomes the best opportunity to regain some kind of human equality, even if it has to be recognised as an exception to the norm. The one important fact is that this exception is provided for by law. As a criminal, even a stateless person will not be treated worse than another criminal, that is, he will be treated like everybody else. Only as an offender against the law can he gain protection from it. As long as his trial and his sentence last, he will be safe from that arbitrary police rule against which there are no lawyers and no appeals. The same man who was in jail yesterday because of his mere presence in the world, who had no rights whatever and lived under threat of deportation, or who was dispatched without sentence and without trial to some kind of internment because he had tried to work and make a living, may become almost a fully-fledged citizen because of a little theft. Even if he is penniless he can now get a lawyer, complain about his jailers, and he will be listened to respectfully. He is no longer the scum of the earth but important enough to be informed of all the details of the law under which he will be tried. He has become a respectable person.' 38

Clearly, this passage contains multiple terms that need further elaboration, as well as what are surely many instances of overstatement. There are also various slides between ideas of 'law' and 'human rights' and 'citizenship' that need clarification. And yet, even with these problems, it is an intriguing passage that deserves close attention. It is helpful to start with Arendt's proposition that by virtue of the institutional response to his crime, the stateless-person-comecriminal becomes 'almost a fully-fledged citizen,' or, indeed, 'a respectable person.' The interest of this point lies in its emphases on relationality and the importance of frame in generating that relationship between the statelessperson-come-criminal and those with authority over him. Like all statuses, that of the 'respectable person' has meaning only as a way that one might be envisaged and evaluated by others: this point is as clear here as it is generally. But here what is specifically notable is how the status in question is entirely institutionally driven. It is the surrounding legal institutional frame and the ethos that its processes demand from those who participate within them that constitutes a way of communicating with the criminal that transforms him from a mere human, or 
worse, 'the scum of the earth,' into someone 'important enough to be informed of all the details of the law under which he will be tried.' Without that frame, however, there is no such status. Indeed, Arendt captures this point when she goes on to tell us that the real significance for personhood is to be found in 'the right to live in a framework where one is judged by one's actions and opinions. '39

These ideas can then be found in repackaged form later in The Origins of Totalitarianism when Arendt elaborates her analysis of the 'road to total domination' and its three kinds of annihilation of the person. ${ }^{40}$ First, she explains, there is the killing of the "juridical person. ${ }^{41}$ Then there is the murder of the 'moral person. ${ }^{42}$ Finally, there is the destruction of 'individuality. ${ }^{43}$ The order of this three-step, we are told, is crucial, because without the threshold annihilation of the juridical person, the other two modes of destroying personhood could not occur.

What, therefore, is it about this status of 'juridical personhood' that stands as such an obstacle to total domination that it must be broken down in order for totalitarianism to be possible? Arendt's answer to this question can be extrapolated from her account of the logic of the centerpiece of the institutional apparatus of totalitarianism, the concentration camp. Here, she explains, the killing of the juridical person 'was done, on the one hand, by putting certain categories of people outside the protection of the law,' and on the other, 'by placing the concentration camp outside the normal penal system, and by selecting its inmates from outside the normal judicial procedure in which a definite crime entails a predictable penalty. ${ }^{44}$ This detachment of the concentration camp from the 'normal penal system' is what in turn informs Arendt's insistence that the criminal does

39 Arendt, The Origins of Totalitarianism, 296, and alternately described as 'a place in the world which makes opinions significant and actions effective' (295). This, Arendt suggests, 'is one of the reasons why it is far more difficult to destroy the legal personality of a criminal, that is of a man who has taken upon himself the responsibility for an act whose consequences now determine his fate, than a man who has been disallowed all common human responsibilities': 300 . See also: '[o]ne of the surprising aspects of our experience with stateless people who benefit legally from committing a crime has been the fact that it seems to be easier to deprive a completely innocent person of legality than someone who has committed an offence': 295.

40 Arendt, The Origins of Totalitarianism, Part III, 'Totalitarianism,' Chapter 12, 'Totalitarianism in Power,' subsection III, 'Total Domination', esp. 447-55.

41 Arendt, The Origins of Totalitarianism, 447.

42 This second step 'in the preparation of living corpses' is, Arendt explains, effected 'through the creation of conditions under which conscience ceases to be adequate and to do good becomes utterly impossible': Arendt, The Origins of Totalitarianism, 452.

43 Once the moral person has been killed, Arendt tells us, "the one thing that still prevents men from being made into living corpses is the differentiation of the individual, his unique identity.' This 'killing of man's individuality, of the uniqueness shaped in equal parts by nature, will, and destiny,' she argues, 'creates a horror that vastly overshadows the outrage of the juridicalpolitical person and the despair of the moral person,' for to destroy individuality 'is to destroy spontaneity, man's power to begin something new out of his own resources': Arendt, The Origins of Totalitarianism, 453, 454, 455. The connections here to Arendt's enduring interest in 'natality' - the opportunity for politics and world-building that is signalled by every new birth - are obvious.

44 Arendt, The Origins of Totalitarianism, 447. 
not properly belong in the concentration camps; a point that is especially instructive for present purposes. Unlike other categories of inmates, 'only criminals have been sent to the camp in connection with some definite activity': criminals, therefore and moreover, 'at least know why they are in a concentration camp and therefore have kept a remnant of their juridical person.' 45 This stands in contrast to the status of 'the politicals,' whose actions, insofar as they were actions at all, 'are as a rule not covered by the normal legal system of the country and not juridically defined.' 46

Arendt clearly paints in wide brushstrokes here, setting up broad distinctions that might assist us to illuminate the defining machinery and dynamics of totalitarianism. The analysis is obviously imprecise. Nonetheless, three points deserve closer attention. ${ }^{47}$ The first goes to the matter of intelligibility; to how the criminal knows, or understands, why he has found himself in interaction with the legal system. This, we are told, is because he has acted in a manner that is "juridically defined,' and so understands, or at least has the conditions to understand, the interface between this 'definition' and the response to him on the part of the institutional order within which he finds himself positioned. All of this, we are invited to extrapolate, is central to possessing 'juridical personhood.'

Second, we should notice how Arendt gives much weight - as is also the case in the 'Perplexities' analysis - to how the criminal is an actor. He is being judged for his actions, and not, like other inmates of the camps, for his mere identity or opinions. Therein lies the key difference between the criminal and the innocent person within the structure of the camps: the criminal encountered the institutional apparatus of authority because he was an actor who acted, unlike the innocent person who did not in the relevant instance exercise that capacity. In this connection to action, too, we are told, the elements of juridical personhood are signalled.

Third, Arendt's analysis clearly suggests that these key ideas are mutually constituting. What I mean here is that the very idea of the juridical person is presented as an aspect of the particular mode of institutional response to an actor whose actions have brought him into its realm, and in this sense, as inseparable from it. The 'juridical,' we might therefore say, marks out a particular quality of institutional response to persons that places recognition of agency, and the sustenance of conditions of intelligibility as between the agent and authority, at its centre. It

My emphasis.

Arendt, The Origins of Totalitarianism, 448-9.

Others before me have also been intrigued by what Arendt seeks to convey in these comments. Goldoni and McCorkindale, for instance, read Arendt as suggesting here that the criminal 'was already a "legal" person: his crime was defined by law; his criminal status was determined by the legal process; his punishment (should he be found to fall within that category) was both contestable (for example, by appeal) and predictable (as prescribed by law). The criminal, therefore, was by definition a rights-bearing individual judged for his unlawful actions': Goldoni and McCorkindale, 'Introduction,' Hannah Arendt and the Law, 8. My own analysis resonates at multiple points with this summation. 
is in turn absent in the absence of such conditions. This helps us to see why 'the juridical person in man' must be killed as a prerequisite to totalitarian domination: because the realm of the juridical is defined by the presence of an institutional structure within which recognition of the person as an individual centre of initiative is sustained. By sustaining that individuality, the juridical structure limits an authority's power to do as it pleases with the juridical person. Authority expressed through the mode of the juridical cannot be otherwise.

All of this, I think, can be readily taken from the resources just reviewed. But further cues from elsewhere in the same analysis strengthen this interpretation. For example, there is something salient to be learned from the emotion that Arendt associates with the killing of the juridical person, that is, how she speaks not of the 'despair' of the moral person rendered dead in his inability to engage in moral action, but of the 'outrage' of the person who understood her relationship to the political order in juridical terms, and expected to be treated accordingly. ${ }^{48}$ Moreover, because these expectations must themselves be generated, the presence of an institutional structure capable of constituting and sustaining a predictable interaction between the person and authority is implied. Indeed, Arendt indicates this explicitly when she suggests that the status of juridical personhood is present in any moment of law's administration where the stability of law mediates the projection of political authority over the agency of persons. This idea emerges from observations she makes about the precariousness of 'totalitarian legality,' which, in its defining commitment to a 'law of movement' that releases 'the fulfilment of law from all action and the will of man,' is a condition constantly under threat. ${ }^{49}$ Though the question with which Arendt is engaged here requires a longer discussion, the point of interest for present purposes is how she uses the term 'legality,' in the context of discussing 'totalitarian legality,' in a positivistic sense. That is, 'legality' ostensibly describes whatever the relevant officialdom declares to be such, a totalitarian officialdom included, with no greater normative story to be told.

We have, therefore, an apparent tension within Arendt's analysis between an essentially 'anything goes' conception of 'legality,' and an idea of the 'juridical' that appears to make strong normative demands on a site of political authority and the corresponding actions of legal officials. It is perfectly likely that Arendt was not aware of the contrast she had set up, and so simply did not think this point through. But even if so, this need not preclude us from digging more deeply into the apparent contrast between Arendt's idea of 'legality' and her much more normatively rich idea of the 'juridical.'

We need not look far for illumination here, because Arendt herself sustains this contrast when she suggests that totalitarian 'legality' could not have its own 'juridical person.' This, she explains, is because totalitarianism is threatened by any context in which relational expectations between persons might spring up in 
a way that generates its own normativity, and so thwart - or at the very least undercut - the totality of the project of total domination. Even by restricting what is otherwise an arbitrary persecution to certain categories of persons (for example, restrictions drawn on religious, political, or other grounds), she argues, would have the effect of rendering the camps 'superfluous,' because 'any stability at all,' even in this context, 'could not fail to produce a new juridical person in man, that would elude totalitarian domination. ${ }^{50}$ Once again, there is surely much overstatement at work here, in terms of what Arendt proposes can emerge from any shred of institutional stability and the relational expectations there generated. Clearly the overall circumstances matter to how attenuated a status of personhood ultimately emerges from a given condition of stability, especially those as narrowly conceived as in Arendt's example. Still, the point to highlight is how stability is crucial to generating the condition of 'juridical personhood' that totalitarianism must eradicate in order to pursue its project, and guard against when that project is afoot. 'Legality' in her usage might have its meaning up for grabs, but the idea of the 'juridical' is clearly not exhausted by the norms of the positive law. It is instead aligned with the status of personhood that is generated out of the stabilities of law's wider institutional complex. ${ }^{51}$

The point of interest, theoretically, thus lies in how in her elaboration of things 'juridical' Arendt offers us a distinctly normative conception of what this condition is and must be. ${ }^{52}$ The juridical condition, and so also the juridical person, comes into being when political authority towards persons is expressed through an institutional order that bears attributes of stability such as predictability, intelligibility, and contestability. Through these attributes, the agents of a juridical order are compelled to recognize and to speak to the persons with whom they engage as centres of initiative. In doing so, they necessarily limit their own authority in favour of that status. Thus, like the 'legal' in Fuller's jurisprudence,

50 Arendt, The Origins of Totalitarianism, 451. A similar point is made when Arendt argues that totalitarianism strives 'not toward despotic rule over men, but toward a system in which men are superfluous. (...) Therefore character is a threat and even the most unjust legal rules are an obstacle; but individuality, anything indeed that distinguishes one man from another, is intolerable': Arendt, The Origins of Totalitarianism, 457 (my emphasis). There is considerable similarity between these arguments and my own analysis of Nazi law in Kristen Rundle, 'The Impossibility of an Exterminatory Legality: Law and the Holocaust,' University of Toronto Law Journal 59 (2009): 65-125.

51 My analysis here seems well supported by remarks that Arendt made some time later in her essay on civil disobedience that I engage with directly below on different grounds. There she suggests that "where the so-called "laws" of history or nature (...) as they are interpreted by the head of state, maintain a "legality" that can change from day to day and that claims validity for all mankind - we are in fact confronted with lawlessness, though not with anarchy, since order can be maintained by means of compulsive organisation': Hannah Arendt, 'Civil Disobedience,' in Crises of the Republic (Orlando: Harcourt Brace, 1971), 79 (my emphasis).

52 Goldoni and McCorkindale's comment that 'it was nevertheless at this precise moment - when she discovered law's futility - that Arendt was awakened to its importance, and even to its meliorative potential. It was, after all, the juridical person in man which stood as the first and most resistant obstacle to total domination and, worse still, extermination' would appear to support this point; Goldoni and McCorkindale, 'Introduction,' Hannah Arendt and the Law, 6. 
the 'juridical' in Arendt's thought designates a particular way of envisaging and treating subjects of political authority, which is in turn constitutive of the status of juridical personhood. And, crucially, both the condition and the status exist only in so far as they are institutionally constituted and sustained through an appropriate ethos on the part of the relevant juridical actors. When this lapses, so does the juridical condition, and with it, the status of juridical personhood.

\section{Analysis and development}

The foregoing discussion will hopefully have made clear that when Fuller and Arendt look at the status of the person within a relationship framed by law, they pay close attention to how that status is generated by the formal features and corresponding participatory commitments of that surrounding legal frame. In so doing, they each draw out the significance of the public legal form for personhood. Indeed, we see not just in Fuller but also in Arendt how the status of the person as a responsible agent, or centre of initiative, is not something separate to the form of things legal, or juridical, but part of them.

What we also receive, if more implicitly in Arendt, is the idea that both positivism and instrumentalism are theoretically insufficient perspectives to comprehend these dynamics and their implications. The insufficiency of the instrumentalist perspective was, of course, among Fuller's central complaints against positivism. This was expressed in perhaps its clearest form in the argument about managerial direction that I recounted in section 3; that is, that the only way an 'efficacy' or purely instrumentalist reading of the value of the principles of the internal morality of law can be sustained is if it is attached to a conception of law that might better be described as a conception of managerial direction. But the complaint against instrumentalism can also be found elsewhere in Fuller's replies to positivism, and in its various formulations consistently conveys the message that positivism invariably gives only passing consideration, if any, to 'the problem of maintaining legality. ${ }^{53}$

Arendt's engagement with the same point is, as noted, much more implicit. But what is clear is that her entire analysis of the phenomenon of the juridical person is non-instrumental in its orientation. That is, for Arendt it would appear to be beside the point whether it is the instrumental intention on the part of those who design and administer the legal institutional frame within which the statelessperson-come-criminal finds himself to effectively turn him into 'a respectable person.' Indeed, surely the main point of the analysis is to highlight the irony of this apparent outcome. Arendt's point instead relates to what comes with the territory of framing a relationship with the criminal in this way, namely, something of profound political significance to the person concerned. It is precisely this that an analysis confined only to the instrumental purposes of that legal frame would miss. 
Thus, if we look at the substantive message conveyed in these materials, we can discern, in both, the separation of considerations going to the positive or instrumental intentions of a legal frame from normative inquiry into what actually sustains a condition of legality. The latter, obviously, embraces a wider arc of inquiry than the former. But Arendt's specific points of focus take us still further towards the development of a distinctive perspective for public legal theorizing through how she highlights the profound political significance of the legal form for those positioned within it, and how this is generated by the character of the relational structures it constitutes and sustains. The point we are invited to take from Arendt's analysis of juridical personhood is that this form is itself political.

What, then, of Fuller on this point? I suggested at the outset of this article that Fuller's attention to the conditions of being a legal subject reflects a direct engagement with law's political significance for persons. As noted there, an idea of 'publicness' is implicit in the very idea of legal subjectivity, because to speak of being a 'legal subject' is to speak in a vocabulary that has meaning only when the circumstances at issue concern the place of persons within a public realm of law. But the 'public' elements of Fuller's program are detectable in other ways, too. In fact, what is striking about how his exchanges with Hart ultimately developed is that although Fuller began as a private law rather than public law thinker, in so far as he was a scholar of contract law, the arc of his jurisprudence actually became more explicitly 'public' in orientation as a consequence of the turns that his debate with Hart took. Over the course of that debate, Fuller's broad concern with the constitutive features of law as a 'facility for living together' comes to translate into a set of arguments about relationships of legality in a more specifically political sense. This movement is clearly driven by what Fuller sees as being deficient in positivism. In The Morality of Law, as noted above, he complains about how 'the problem of achieving and maintaining legality' seemed worthy of 'no more than casual and passing consideration' in Hart's project. ${ }^{54}$ We equally find arguments about the ethos of 'trusteeship' that arises from how the lawgiver's role implicates a 'responsibility to persons generally. ${ }^{55}$ And we must of course also recall the thrust of his position on the question of why we would have 'fidelity to law.' Such arguments surely signal a particular, distinctly public, story about the relationships sustained, rather than diluted, through and within the legal condition. ${ }^{56}$

Moreover, to my eyes at least, the permeability of Fuller's jurisprudence to a background story about political order is readily discernible, even if he mostly leaves

54 Fuller, The Morality of Law, 153.

55 See Chapter 4, Forms Liberate re this neglected element of Fuller's argument, and how this neglect can be traced to Hart's 1965 review: Rundle, Forms Liberate, 105-8.

56 See also Fuller's comments on how the debasements of Nazi law took place in the realm of public law (and in private law only if the political status attributed to Jews brought about a change in private law relations - otherwise, private law among Aryans remained essentially 'un-Nazified,' precisely because the Nazi legal transformation was an essentially public law project): 'Positivism and Fidelity to Law,' 600-61. 
us to speculate on what the expected content of such an account might be. ${ }^{57}$ At its very simplest, and taken from what registered in his legal theorizing, one would expect such an account to emphasize the capacities of the person as an agent, and thus be at its essence participatory and democratic in flavour. ${ }^{58}$ Further, if we pay attention to his 'fidelity to law' analysis and what it suggests to us about the background political ideas that register in his account of the conditions for legal authority specifically, one would equally anticipate an account of authority that is consistent with and respectful of those human aspirations and capacities. ${ }^{59}$ This, I would propose, is at the very minimum of what is displayed in Fuller's reflections on things legal in a public, subject-centred sense.

Moving to how we might understand the methodological demands placed on normative public legal theory of the kind of interest here, there are a number of instructive insights to draw upon from Fuller and Arendt alike. The first and most

57 I would suggest that this is the case from Fuller's earliest criticisms of legal positivist philosophy, and its insulation from social, moral, and political questions. This isolation of things legal is the theme of his first book, The Law in Quest of Itself (Chicago: The Foundation Press, 1940), where among other points of criticism we find Fuller's complaint that although modern legal positivism is widely regarded as deriving its lineage from Hobbes, and specifically his model of a sovereign lawgiver who rules through positive law, what modern legal positivism misses is something that is crucial in Hobbes' account: namely, the reasons, or purposes, for arriving at that positive law system in the first place: 19-20. On this point at least, the fact that Law in Quest of Itself was published in the 1940s, and so predates Hart's interventions, would not appear to be material to the continuing applicability of the general criticism that Fuller there advanced. Indeed, this point leads to matters of methodology that I take up immediately below.

58 However ultimately under-developed, Fuller's intended project on freedom, with its emphasis on neglected aspects of the conception of positive freedom, as well as his intended project on democracy, would seem to support such a speculation: see Kenneth Winston's editorial note to 'The Case Against Freedom,' in The Principles of Social Order, 315. Notes for both projects can be found in the archive of Fuller's private papers held at the Harvard Law School Library.

59 I will leave for another occasion the question of the likely key features and commitments of an account of authority appropriate to the kind of public normative legal theory that I have been exploring here. But beyond the gestures already made about how Fuller's thought might contribute to the development of such, it is worth noting that there is little in Arendt's reflections on the juridical person to suggest the presence of resources through which to explore an account of the conditions for legal authority specifically (that is, as opposed to her thinking on the question of political authority). That said, we do receive hints of her thinking on this point in an essay on civil disobedience where she engages directly with the question of the breakdown of the obligation to obey the law. The right view of the genesis of this obligation, as Arendt sees it, is to view the moral content of consent to the law in the same terms as the moral content of all agreements: that is, as consisting in 'the obligation to keep them' that is 'inherent in all promises.' Consent to law is therefore in this sense not 'mere acquiescence, with its distinction between rule over willing subjects and rule over unwilling ones,' but rather a kind of 'active support and continuing participation in all matters of public interest.' However, the citizen's obligation to 'give and keep reliable assurance as to his future conduct' is not unconditional. We are bound to keep our promises only 'provided that the mutuality inherent in all promises is not broken,' as might occur in 'the failure of established authorities to keep to the original conditions.' See Arendt, 'Civil Disobedience,' 92, 85, 92, and 93. Again, therefore, we see broad commonality with Fuller, in so far that mutuality, or reciprocity, lies at the core of the conditions that can conceivably sustain an agent's acceptance of law's claim to authority over her, rendering the notion of unconditional obligation meaningless. 
obvious is the subject-centred perspective itself: that is, how both explore the characteristics, commitments, and dynamics of the legal/juridical condition through an assessment of the position occupied by the person within it. Indeed, we could confidently expect both Fuller and Arendt to be resistant to the deflationary response that a 'legal subject' is merely a bearer of 'legal rights,' without regard to the 'exercise-ability' of those rights. The notion of 'exercise-ability' would seem to be included within, not additional or optional to, their accounts of the legal or juridical respectively. ${ }^{60}$ To demand such, however, is not without its complications, because what is needed is not just an orientation towards the legal subject. It also requires a wider methodological attitude that regards how a person actually experiences the legal frame around her as central to the value of the theoretical perspective ultimately offered. Yet to make actual legal experience so important surely generates an expectation of socio-legal inquiry more than it does theoretical inquiry. ${ }^{61}$ How, then, to proceed?

Arendt would not likely have been troubled by this question: her 'phenomenological' methodological orientation supported the belief that 'thought itself arises out of incidents of living experience and must remain bound to them'. ${ }^{62}$ In legal theory, however, especially the kind which came to frame the articulation and reception of Fuller's jurisprudence in the Hart-Fuller debate, the case for bridging the theoretical and the sociological (or empirical) remains a contested one. Fuller himself resisted his detractors on this point as forcefully as he could: his critics' apparent insistence on insulating their theoretical reflections from 'everyday legal experience $^{\prime 63}$ formed the subject of many a complaint. This is especially seen in his appeal to his critics to test their claims against 'the prosaic facts of human life, ${ }^{64}$ his insistence that 'definitions' of law are 'direction posts for human experience, ${ }^{65}$ and other arguments that counsel legal theorists to ensure that theory and practice mutually inform each other. ${ }^{66}$

These complaints have found renewed and sophisticated expression in the work of a number of contemporary legal theorists who are dissatisfied with the

60 This is why, in earlier work, I state that the conception of legal subjectivity I associate with Fuller's jurisprudence is 'considerably more demanding than one that asks no more of such a conception than that a person possesses legal rights.' There is, I argued there, 'a crucial difference between possessing something and expressing it; between having the capacity, as well as the conditions, to actually experience a relationship to law, and not having that capacity or those conditions': Rundle, 'Law and Daily Life,' 435.

61 Thanks to Lael Weis for pressing me on this point.

62 Hannah Arendt, Between Past and Future (London: Penguin, 1977), 14.

63 Fuller, 'Positivism and Fidelity to Law,' 646.

64 Fuller, 'A Reply to Professors Cohen and Dworkin,' Villanova Law Review 10 (1965): 664-6.

65 Fuller, 'Positivism and Fidelity to Law,' 632.

66 See especially how Fuller's final 'Reply to Critics' closes with the hope that future legal philosophers would 'cease to be preoccupied with building "conceptual" models to represent legal phenomena, will give up their endless debates about definitions, and will turn instead to an analysis of the social processes that constitute the reality of law': Fuller, 'Reply to Critics,' 242. 
abstract philosophical methods of 'conceptual analysis,' and the 'Archimedean'67 methodologies they employ. We are seeing, as a result, an increasing desire to incorporate institutional experience and practice into the theorization of legal arrangements as well as core legal concepts. A leading proponent of this trend is Nicola Lacey. ${ }^{68}$ For Lacey, the general lack of attention among legal theorists to the relationship between a given conceptualization or theory of law and the actual institutions or practices in question is lamentable, and signals the clear need for methodological approaches that allow the institutional conditions for the existence of legal arrangements to 'inflect our theory-building. ${ }^{69}$

What is especially notable for present purposes is how, when revisiting resources that might aid the development of such an agenda, Lacey acknowledges that Fuller's project presented an exception to the general trend in its vision for a 'theorised legal scholarship which engages in a serious way with law's institutional forms, and which draws upon the insights of other disciplines in doing so, ${ }^{\prime 70}$ even if that agenda was ultimately under-developed amid the incompletely synthesised quality' of Fuller's varied scholarly interests. ${ }^{71}$ Similarly, in framing her case for addressing the methodological gap between the philosophical study of legal concepts and arrangements and the social sciences, Lacey specifically comments that while 'the delineation of the criteria marking out legal subjects or persons' is a key concern of any legal system, it has been received in the philosophical literature with an 'uneven interest in the broader social, institutional and cultural

67 I evoke here Ronald Dworkin's charge that, in methodological terms, legal positivism is 'Archimedean' in its perspective, rather than rooted in actual institutional experience: see 'Hart's Postscript and the Character of Political Philosophy,' Oxford Journal of Legal Studies 24(1) (2004): 137.

68 Another key example is Frederick Schauer's 'non-essentialism,' which advocates a methodological approach to legal theory that reflects upon pervasive features of actual legal systems in a manner that, though intended to meet a certain standard of theoretical generality, is nonetheless rooted in actual social and legal practices: see Frederick Schauer, The Force of Law (Cambridge: Harvard University Press, 2015).

69 See Nicola Lacey, 'Institutionalising Responsibility: Implications for Jurisprudence,' Jurisprudence 4(1) (2013): 1-19, at 1 and 3.

70 Nicola Lacey, 'Out of the "Witches Cauldron"? Reinterpreting the Context and Reassessing the Significance of the Hart-Fuller Debate,' in The Hart-Fuller Debate in the Twenty-First Century, ed. Peter Cane (Oxford: Hart Publishing, 2010), 1-42, at 42.

71 Lacey, 'Out of the "Witches Cauldron"?,' 32. Drawing on her biographical research on Hart, Lacey elsewhere suggests that Hart's working notebooks also have hints of 'a wider ambition to facilitate a degree of complementarity between jurisprudence and the social sciences, and an aspiration that jurisprudence be of use to social scientists and socio-legal scholars': see Nicola Lacey, 'Analytical Jurisprudence versus Descriptive Sociology Revisited,' Texas Law Review 84 (2006): 945-82, at 949. I acknowledge Kevin Walton's article, 'Legal Philosophy and the Social Sciences: The Potential for Complementarity,' Jurisprudence 6 (2015) (forthcoming) for bringing this resource to my attention. Indeed, much of what follows finds strong support in the methodological prescriptions advocated in Walton's analysis. 
conditions under which these legal concepts have developed and by which they have been shaped. ${ }^{72}$

The resonances between Lacey's remarks and present concerns are clear on several levels. But whether one opts for Lacey's proposed approach or some other, one must still confront the question of how such an agenda might be realized within theoretical practice. To gesture to at least the direction of an answer to that question with the concerns of the present article in view, two approaches would seem to be especially salient. First, we might pursue empirical investigation into individual subjective experiences of legal institutions and processes in the manner of socio-legal research, with a view to providing fruit for theoretical reflection. Or, in a manner less beholden to the subjectivities of individual experiences, yet maintaining a concern to engage directly with the life of institutions in practice, we might seek ways to examine the capability of the legal institutional frame itself - whatever its specific features across different contexts - to generate and sustain the kind of treatment of the person that is signalled by the idea of the legal in Fuller and the juridical in Arendt. ${ }^{73}$ These two approaches need not be considered in isolation from each other: indeed, the latter, more 'external' appraisal of legal conditions would likely shed much light on why a subject's experience of such conditions has the character that it does.

Still, if opting for the latter approach, standards through which to measure such 'capability' will clearly be necessary, and this in turn suggests that some kind of normative model to guide an assessment of capability must be available to lead the empirical investigation. It might well be, therefore, that the best place to start in exploring such an approach is to revisit what Fuller had in mind when he associated the possibility of declaring a given condition to be a 'legal' one with the extent to which it materialized his principles of the internal morality of law. If we were to follow Fuller's lead here, however, it is crucial that we understand those principles not as a prescriptive checklist of inflexible criteria appropriate to all modalities and situations. His model of 'the internal morality of law' must, as I earlier clarified, instead be read as an attempt to articulate, in formal terms, the relationship between authority and subject that is envisaged by his idea of

72 Lacey, 'Out of the "Witches Cauldron"?', 4, 5. This way of approaching questions concerning legal personhood, Lacey suggests, 'is one initial clue to the very particular way in which legal philosophers have drawn the boundaries of their intellectual concern' (5).

73 Normatively, this idea of capability also embraces an inquiry into whether a given legal institutional complex is 'capable' of delivering upon what it claims for itself. This sense of the capability idea is central to Joseph Raz's account of law in its specific focus on the conditions for legal authority. That is, according to Raz, a key feature of law is that it makes claims to its own legitimate authority: law in actuality might not possess this legitimate authority, but even so, it does need to be able to claim it for itself, and, crucially, to be capable of claiming that which it claims for itself. Relevantly to the present inquiry, however, I have elsewhere suggested that an unspoken aspect of Raz's 'capability condition' is that it presupposes a surrounding form that supports such capability: see Kristen Rundle, 'Form and Agency in Raz's Legal Positivism,' Law and Philosophy 32 (2013): 767-91. In using the term 'capability condition,' I invoke the language used by Noam Gur to capture this emphasis I have sought to tease out in Raz's work on authority: see Noam Gur, 'Form and Value in Law,' Jurisprudence (5(1) (2014): 85-95, at 93. 
legality. But the primary point I want to emphasize is that openness to the sociological, to the actual life of legal institutions and the experience of the subject within them, is fundamentally important to developing this perspective.

Indeed, this openness to the empirical is also crucial for other reasons that go to the inherent limits that would appear to attach to normative theorizing in the first place. What I am gesturing to here is how the impulse to articulate normative standards tends to be driven by some kind of relationship to a pathological case: that is, to a phenomenon that triggers the intuition that a line in the sand has been crossed. The character of Fuller and Arendt's reflections on the legal subject and the person respectively illuminate precisely this aspect of normative theorizing. When Fuller explores what it means to be a legal subject, he proceeds 'negatively' by emphasizing what happens in the degeneration and ultimate absence of law's frame. Arendt, by contrast, proceeds from the more 'positive' perspective of what is generated, in terms of the status of personhood, through the transformative effects of the juridical frame: that is, she emphasizes less what is lost through the loss of the juridical, than what is gained through it, even if the wider context of her analysis concerns precisely the fundamental deleterious effects of the loss of rights. The point, however, is that both analyses anchor their arguments in, and so hover around, some kind of crisis point. It is this that begs the question of whether it is perhaps inherent to the project of normative theorizing, on matters legal or otherwise, to be ultimately married to minima; to standards that assist us to identify moments of breach and transgression much more readily than they do conditions for flourishing. This is clearly a challenge to the possibilities and limits of normative legal theorizing to be explored in its own right. But it is also one that signals the importance, to such an enterprise, of socio-legal investigation into how the life of a legal institution, in terms of its interaction with conditions of personhood and generally, actually plays out in practice.

\section{Conclusion}

It is helpful to bring the foregoing to a close by returning to Arendt's and Fuller's common criticism of the command conception of law. Both, I would suggest, saw the danger with theorizing law in terms of the command conception as lying not (or not primarily) in a problem of mis-description, but in how such presents a subjugation of the person in the face of political authority, in the name of law. Both, therefore, saw a need to return to or develop conceptions of law that reversed these implications for personhood. For Arendt, the priority was that any such conception would embrace a more capacious and political conception of freedom; a possibility which necessarily rests on a conception of the legal subject herself as a site of and for action. For Fuller, the required conception of personhood was somewhat loosely cast: he variously described it in terms of 'responsible 
agency,' a capacity for 'self-determination,' a 'bearer of dignity,' and other terms. ${ }^{74}$ But, I would suggest, common to both is an awareness of how the consequences of portraying the character of law exclusively in terms of its emanation from a source of authority register, in a material way, in how the figure of the legal subject is envisaged, and what picture of life under law a given theory draws for her.

In its exploration of the possible substantive claims and methodological commitments of a direction of public normative legal theorizing which commences from the position occupied by a subject within a putative legal form, this article has attempted to take this last insight seriously. This has been done, moreover, in the belief that the distinctive perspective of the kind of legal theorizing here sketched is one that we need, for a number of reasons. First, much of the kind of normative 'rule of law thinking' that has traditionally concerned itself with the position of persons in the face of authority is married to models - primarily legislative in character - that are becoming rapidly outdated in the contemporary machinery of government. ${ }^{75}$ In a landscape now characterized by a wide variety of legal forms, private as often if not more so than public, we must ask whether rule of law thinking led primarily by legal institutional type will remain normatively serviceable to the appraisal of that landscape. If that question is answered with even a suggestion of doubt, it follows that there is a need to consider how we might find the centre of gravity of such rule of law theorizing elsewhere; in questions, or constants, that will always be salient.

The proposition I have explored here is that an examination of the position of persons within a (putative) public legal frame, and specifically of the opportunities provided by that frame for the expression of agency, might provide that constant. It might do so, crucially, whatever the specific characteristics of the relevant frame: legislative, contractual, or some other. Thus, though led by Fuller's thought, what has been of primary interest here is the general promise and viability of a mode of theorizing that is person-centred, form-attentive, relationally-oriented, and intrinsically public. Such a project might ultimately run in a number of directions, and gain insight from a range of theoretical resources. Yet, irrespective of those possible directions, the significance of the presence of the distinctive figure of the legal subject, or juridical person, seems to me to be clear. Because is it precisely the presence of this figure that is inseparable from

See Rundle, Forms Liberate, 10 and 99-100. It is not my project to define precisely who Fuller's legal subject is, or what conception of the person (for example, in moral philosophy terms) he has in mind. In Forms Liberate I kept this point open, because Fuller himself kept it open. I address these points at length in my response to the Jurisprudence review symposium on Forms Liberate: see Kristen Rundle, 'Reply,' Jurisprudence 5(1) (2014): 133-60.

75 Or, to recall a point I made earlier, these same 'legislative' conceptions can and have readily lent themselves to exclusively instrumentalist, 'checklist' understandings of the rule of law that, in that exclusive instrumentalism, are arguably more amenable to conceptions of the rule of law that see such rule as directed to the security of private property than they are to the explicitly public current of rule of law thinking that has been of concern here. 
Legal Subjects and Juridical Persons: Developing Public Legal Theory through Fuller and Arendt

the presence of the public realm itself, and so therefore also from an idea of legality that is committed to things public. 